\title{
"AS PRINCIPAIS FORÇAS DOS PIRRÔNICOS" (La 131) E SUA APROPRIAÇÃO POR HUET
}

\author{
José R. Maia Neto* \\ jrmaia@fafich.ufmg.br
}

\begin{abstract}
RESUMO Este artigo tem duas partes. Na primeira, é examinada a apropriação que Pascal faz do argumento cartesiano do Deus enganador no fragmento La 131 dos Pensamentos. Mostra-se ai uma leitura epistemológica cética do argumento de Descartes que o transforma em uma das premissas do argumento pascaliano da verdadeira religião. Na segunda parte, é examinada a apropriação que Huet faz deste mesmo argumento cartesiano no seu Tratado filosófico da fraqueza do entendimento humano (livro I, capitulo 10). Mostra-se nesta parte, com base no Tratado e nas anotações que Huet fez no seu exemplar dos Pensamentos, que a leitura cética huetiana do argumento cartesiano é derivada da leitura pascaliana do mesmo argumento, embora para um fim diferente do de Pascal: não como prova da doutrina da Queda, mas como indicação da fraqueza da razão desprovida da fé.
\end{abstract}

Palavras-chave Deus enganador; Ceticismo; Descartes; Pascal; Huet

\footnotetext{
Professor do Departamento de Filosofia da UFMG e bolsista de pesquisa do CNPq. Este artigo tornou-se possível graças às missões de trabalho em Paris e Caen que realizei no quadro de um projeto CAPESCOFECUB e se beneficiou também de um grant de pesquisa que me foi concedido pela Universidade do Piemonte Oriental em Vercelli. Agradeço aos professores Gianni Paganini, Jean-Robert Armogathe, Thomas Lennon, Vincent Carraud e Gilles Olivo pelas sugestões e apoio e, sobretudo, em memória, a Richard H. Popkin, que foi, até o seu falecimento recente, meu principal colaborador e interlocutor sobre Huet. Artigo recebido entre $1^{\circ}$ e 30 de abril de 2006 e aprovado entre $1^{\circ}$ e 31 de maio de 2006.
} 
ABSTRACT This paper has two sections. In the first I examine Pascal's appropriation in La 131 of the Cartesian argument of the deceiver God. Pascal develops a skeptical reading of the argument in order to use it as a premise for his apologetic argument of the true religion. In the second section I examine Huet's appropriation of this same Cartesian argument in his Philosophical Treatise on the Weakness of the Human Understanding. Based on this work of Huet's and on his marginal notes on Pascal's Thoughts, I show that his skeptical reading of the argument is derived from Pascal's, although Huet's and Pascal's goals are distinct: while the latter intends to provide an argument for the Fall of Man, the former intends to show the weakness of reason unassisted by supernatural faith.

Keywords Deceiver God; Skepticism; Descartes; Pascal; Huet

La 131 é um dos longos fragmentos dos Pensamentos de Pascal. Incluído no folio "contrariedades", ele desenvolve o argumento da verdadeira religião (La 149) ou prova pela doutrina (La 402), cujo objetivo é apontar o valor racional da doutrina cristã, a fim de quebrar resistências intelectuais ${ }^{1}$ e, assim, melhor dispor o leitor para a consideração das provas escriturais. ${ }^{2} \mathrm{O}$ argumento busca mostrar que só a revelação sobrenatural cristã, fundamentalmente a doutrina da queda, é capaz de explicar e solucionar as contrariedades humanas morais e epistemológicas que são somente parcialmente apontadas pelas filosofias pagãs desprovidas da revelação.

Pascal se vale da distinção das filosofias e dos filósofos, feita pelos céticos pirrônicos: dogmáticos (que pretendem ter conhecimento da verdade), novos acadêmicos (que negam que a verdade possa ser conhecida) e os próprios céticos ou pirrônicos (que suspendem o juízo). ${ }^{3}$ Para estabelecer a contrariedade das filosofias pagãs, Pascal reduz os três grupos de Sexto a dois. Associa acadêmicos e pirrônicos, contrapondo-os aos dogmáticos. ${ }^{4} \mathrm{Cada}$ grupo descreve um aspecto verdadeiro da condição epistêmica do homem,

1 "Os homens têm desprezo pela religião. Têm ódio dela e medo de que ela seja verdadeira. Para curar isso, é preciso começar por mostrar que a razão não é contrária à razão. Venerável, dar-lhe respeito. (...) Venerável porque conheceu bem o homem" (La 12).

2 Ver o resumo da conferência de Port-Royal no prefácio de Étienne Périer da edição de Port-Royal de 1670.

3 Sexto Empírico abre o seu Esboços do Pirronismo com esta distinção tripartite. Ver: SEXTO EMPÍRICO, Outlines of Pyrrhonism, PH I.1-3.

4 A edição Lafuma que traz em itálico as partes riscadas por Pascal indica isto. "Não se pode ser pirrônico nem acadêmico (...)"; "A natureza confunde os pirrônicos (e os acadêmicos)"; "Não podeis fugir de uma dessa (três) seitas (...)." 
mas desconsidera o aspecto contrário igualmente verdadeiro. Os pirrônicos mostram bem a impossibilidade de a razão fundamentar o conhecimento, mas se equivocam ao achar que podemos suspender o juízo sobre tudo. Os dogmáticos mostram bem que não podemos suspender universalmente o juízo, que algumas crenças se impõem, mas se equivocam ao supor que estas crenças possam ser fundamentadas. A doutrina da queda, com a dupla natureza do homem por ela implicada, explica e concilia esta contrariedade: o conhecimento era possível no estado de inocência, não é mais no da queda, mas restam vestígios da situação pré-lapsária que, em última análise, explicam a impossibilidade da épochè. A filosofia pagã se destrói na contraposição irresolúvel no terreno da mera razão entre dogmatismo e "pirronismo" (no sentido pascaliano), cujas insuficiências conferem credibilidade intelectual à doutrina cristã.

Com este argumento, Pascal se insere numa longa tradição de utilização apologética do ceticismo antigo. Tal utilização começa com Santo Agostinho e os padres fundadores, mas se amplia consideravelmente a partir do Renascimento, quando, graças à disponibilização dos textos de Sexto Empírico, o pirronismo e seu rico manancial de argumentos antidogmáticos passa a ser empregado juntamente com os do ceticismo acadêmico, únicos conhecidos pela cristandade até o século XVI. ${ }^{5}$ Entretanto, o uso do ceticismo por Pascal é mais complexo do que o uso renascentista e do início do século XVII, que podemos caracterizar como fideísta. ${ }^{6} \mathrm{O}$ fideísta usa o ceticismo como uma espécie de preambulo fidei negativo, removendo falsas doutrinas dogmáticas que estorvam o único acesso legítimo à fé, um acesso necessariamente não racional, que pode ou não ser sobrenatural. Em Pascal, o ceticismo não é o ponto de partida filosófico, num certo sentido, antifilosófico, que prepara a aceitação da verdade sobrenatural da revelação cristã. O caminho de Pascal é o inverso. Um certo ceticismo limitado (epistemológico, mas não moral ou psicológico) é o resultado da verdade da revelação cristã. Não se trata, portanto, de levar o interlocutor a um ceticismo para facilitar a sua aceitação da revelação cristã, mas mostrar ao cético que tanto o que sua posição tem de correto quanto o que ela tem de equívoco ou deficiente explicam-se pela aceitação da revelação cristã.

5 Os poucos manuscritos medievais das obras de Sexto não tiveram nenhum impacto digno de nota na filosofia ou teologia escolástica.

6 O termo é anacrônico, mas caracteriza bem o tipo de uso do ceticismo por estes filósofos. O que caracterizo como "fideísta" é a articulação entre a razão e a fé, na qual a primeira tem o papel apenas negativo de remover crenças. Uso o termo em um sentido neutro no que concerne à questão do posicionamento pessoal do filósofo a favor ou contra a religião. 
Um certo ceticismo - assim como um certo dogmatismo - é portanto chancelado pelo cristianismo. Se, por um lado, a apropriação pascaliana do ceticismo é mais crítica do que a dos fideístas, na medida em que, contrariamente a estes, o ceticismo é visto por Pascal como uma posição inconsistente e insatisfatória; ${ }^{7}$ por outro, Pascal traz o ceticismo para o interior do cristianismo. Por exemplo, na utilização pascaliana da divisão tripartite da filosofia por Sexto, o cristianismo toma o lugar do pirronismo, que em Sexto era a alternativa genuinamente não dogmática à contraposição dogmatismo versus nova academia (entendida por Sexto como um dogmatismo negativo). Em La 109, Pascal contrapõe dogmáticos, que afirmam uma total clareza da luz natural, aos acadêmicos que sustentam uma total obscuridade. ${ }^{8}$ Esta contraposição, diz Pascal, "[glorifica] a cabala pirrônica que consiste nessa ambiguidade ambígua, e em certa obscuridade duvidosa de que as nossas dúvidas não podem tirar toda a clareza, nem as nossas luzes naturais espantar todas as trevas". Esta mistura de clareza e obscuridade é justamente a condição da verdade, em especial para o homem decaído, o estatuto epistêmico da verdade cristológica e da verdade escritural. ${ }^{9}$

A maior complexidade do uso do ceticismo por Pascal tem duas causas fundamentais. A primeira é seu agostinismo teológico, sua concepção da natureza corrompida, que o fez pensar o ceticismo como sintoma desta corrupção. Este ceticismo anti-humanista de raiz teológica está ausente dos principais filósofos e teólogos que utilizaram o ceticismo antigo para fins apologéticos. ${ }^{10}$ Explorei este viés em outro trabalho. ${ }^{11}$ Aqui quero me debruçar sobre alguns aspectos da segunda causa: a influência de Descartes.

7 Contrariamente aos céticos fideístas, o ceticismo em Pascal jamais é adotado, até porque jamais ele pode ser efetivamente adotado, a natureza impedindo a suspensão do juízo.

8 A visão que Pascal tem do ceticismo acadêmico seria, até recentemente, vista como equivocada, dada a hegemonia da interpretação dialética desta escola antiga entre os estudiosos. Hoje, entretanto, começa a ganhar força a interpretação de que os acadêmicos tinham sim posições filosóficas, embora não dogmáticas. A principal posição seria a afirmação da obscuridade das coisas, concordando com a leitura de Pascal. A estudiosa que defende esta interpretação é A. M. Ioppolo, em Opinione e Scienza. II debattio tra Stoici e Academici nel III e nel II secolo a c. Ver também a tese de Roberto Bolzani Filho, Acadêmicos versus Pirrônicos. A passagem considerada crucial para corroborar esta interpretação está nos Acadêmicos de Cícero (Academics, Ac I. 34.)

9 Entre outros fragmentos, podemos citar La 236: "Há bastante clareza para iluminar os eleitos e bastante obscuridade para os humilhar. Há bastante obscuridade para cegar os réprobos e bastante clareza para os condenar e torná-los indesculpáveis."

10 Para uma visão diferente para o caso de Montaigne, ver: LIMBRICK. Métamorphose d'un philosophe en théologien, p. 229-246. Para o de Charron, ver: Belin, L'CEuvre de Pierre Charron 1541-1603. Littérature et théologie de Montaigne à Port-Royal.

11 Ver: MAIA NETO. The Christianization of Pyrrhonism: Skepticism and Faith in Pascal, Kierkegaard and Shestov. 
O primeiro ponto a se destacar é que talvez a própria classificação das filosofias pagãs tenha origem não em Sexto, mas em Descartes. ${ }^{12} \mathrm{Na}$ Carta Prefácio à tradução francesa dos Princípios da Filosofia, Descartes faz uma síntese da história da filosofia, contrapondo dogmáticos (Aristóteles e seus discípulos peripatéticos) e céticos. Descartes inclui entre estes últimos: Platão, interpretado por Descartes como parcialmente cético, ${ }^{13}$ os novos acadêmicos (Arecesilau e discípulos) e os pirrônicos. Encontramos em Descartes esta mesma síntese das posições filosóficas da história da filosofia em dois pólos contrários, um cético e outro dogmático. Mais ainda, Descartes apresenta a sua filosofia como a que reconcilia estas duas filosofias contrárias, preservando e corrigindo o que cada uma possui de verdadeiro e rejeitando o que cada uma possui de falso. ${ }^{14}$

Voltemos à estrutura do argumento de La 131 para apontarmos outros aspectos da presença cartesiana. A idéia de Pascal é que toda filosofia poderia se reduzir ou ao dogmatismo ou ao "pirronismo", posições contrárias entre si e ambas igualmente inconsistentes internamente. Só assim o argumento pode conferir credibilidade intelectual à doutrina cristã da queda, que introduz os dois estados do homem responsáveis pelo que cada filosofia tem de verdadeiro e de falso e que são igualmente presentes ou importantes. ${ }^{15} \mathrm{O}$ problema é que Pascal desenvolve muito mais as forças dos pirrônicos do que as dos dogmáticos, estabelecendo um certo desequilíbrio favorável ao pirronismo. Esta situação levou os editores de Port-Royal a enxertarem em La 131 o fragmento La 110, que faz uma crítica explícita aos pirrônicos. La 110 é inserido no ponto de La 131, no qual Pascal diz, depois de detalhar as principais forças dos pirrônicos, que o único ponto forte dos dogmáticos

12 Se a fonte de Pascal é Sexto, certamente não é direta, pois não há nenhuma evidência de que tenha lido as obras de Sexto, mas através de Montaigne, que relata a divisão sextiana tripartite da filosofia na "Apologia", em Os Ensaios, v. II, 12, p. 254.

13 Platão foi interpretado como cético ou parcialmente cético pelos novos acadêmicos e por outros filósofos até pelo menos o fim do século XVII. Este é o caso de Simon Foucher. Ver: MAIA NETO. Foucher's Academic Cartesianism, p. 71-95.

14 DESCARTES. CEuvres, AT IXB, 5-8. La 131 segue o argumento exposto a Sacy no Entretien. Vincent Carraud afirma que "Descartes s'avance masqué [dans l'Entretien]. II y est clandestinement présent non seulement pour radicaliser le doute insuffisant de Montaigne, mais encore au point inouï de contaminer l'interprétation théologique de la philosophie par Pascal (et peut-être sa christologie). Au moment où il avouait dériver insensiblement en théologie, Pascal, en réalité, ne faisait que de la philosophie". [Descartes avança disfarçado no Entretien. Ele está presente clandestinamente neste texto não somente por radicalizar a dúvida insuficiente de Montaigne, mas também no ponto inesperado de contaminar a interpretação teológica da filosofia por Pascal (e talvez sua cristologia). No momento em que Pascal pretendia insensivelmente chegar na teologia, na verdade não fazia mais do que filosofia] ( $P a s c a l$ et la Philosophie, p. 136).

15 Embora a corrupção seja mais visível nos Pensamentos de Pascal do que as reminiscências do estado prélapsário, Pascal afirma o igual peso de ambos os estados em vários fragmentos além do La 131 e também nos Escritos sobre a Graça. 
é que a incapacidade da razão de fundamentar algumas verdades não apaga o nosso sentimento de que são verdades e, portanto, não é capaz de levar à suspensão do juízo, mostrando, ao contrário, a impotência da razão cética. Este reforço dos dogmáticos seria justificado pelos editores de Port-Royal, que apontam o caráter inacabado da obra pascaliana. ${ }^{16}$ Esse caráter não explica, entretanto, a menor elaboração da "principal força dos dogmáticos". Em primeiro lugar, porque, no Entretien com Sacy - um texto supostamente completo -, onde o argumento da verdadeira religião é a espinha dorsal da leitura que Pascal apresenta de Montaigne e de Epíteto - que representam, respectivamente, o "pirrônico" e o "dogmático" -, as forças do pirrônico Montaigne são bem mais desenvolvidas do que a do dogmático Epíteto. Em segundo lugar, mesmo com o reforço de La 110, não fica equilibrada a contraposição entre "pirrônicos" e dogmáticos, uma vez que o argumento de La 110 contra os pirrônicos se aplica igualmente aos dogmáticos, pois se trata de atacar o princípio de integridade intelectual supostamente adotado por ambos os partidos. Embora Pascal vise especificamente aos "pirrônicos", os dogmáticos são igualmente atingidos. ${ }^{17} \mathrm{Se}$ a razão é incapaz de fundamentar a verdade, mas esta se impõe apesar disso, o pirrônico triunfa parcialmente, e o dogmático fracassa totalmente, pois um assentimento não determinado pela razão é tão contrário à atitude do filósofo dogmático como à do cético. Enfim, mesmo quando Pascal contrapõe dogmatismo e "pirronismo", alegando que não se pode permanecer em nenhuma das duas filosofias nem evitar uma ou outra, novamente o "pirronismo" prepondera sobre o dogmatismo, na medida em que uma eventual neutralidade seria, segundo Pascal, neste ponto seguindo Montaigne, uma posição tipicamente pirrônica. ${ }^{18}$

Examinemos agora, rapidamente, as duas principais forças dos pirrônicos: o argumento da incerteza da nossa origem e o argumento do sonho. Um e outro cenário colocam em dúvida o sentimento da verdade dos princípios. Como os editores e intérpretes de Pascal já indicaram, trata-se de argumentos céticos cartesianos e não propriamente pirrônicos nem montaigneanos. $\mathrm{O}$ argumento da incerteza da origem é ausente dos céticos antigos e modernos, ${ }^{19}$

16 Esta é a justificativa alegada no prefácio pelos editores de Port-Royal para intervirem no texto de Pascal.

17 Argumento em "Pascal's Christian versus Charron's Skeptical Wisdom" (inédito) que este fragmento é um ataque à sabedoria cético-acadêmica charroniana.

18 "Expõem suas proposições apenas para combater aquelas em que pensam que acreditamos. Se adotardes a deles, com a mesma facilidade adotarão para defendê-la a oposta; tudo lhes é igual" (MONTAIGNE. Os Ensaios II, 12, p. 255-256).

19 Edwin Curley (em Descartes against the Skeptics, p. 68-69) aponta um possível precedente no argumento acadêmico citado por Cícero nos Acadêmicos (Ac II. 49), mas trata-se, entretanto, de um exemplo de uma sorite envolvendo a deidade bem menos radical do que a hipótese de um deus enganador. Na ARS de Montaigne, fonte principal de Pascal, não há nada parecido com as hipóteses do gênio maligno e do Deus 
e o do sonho tem neles uma estrutura distinta, em que não é jamais questão a possibilidade de toda nossa experiência sensível ser meramente onírica. ${ }^{20} \mathrm{O}$ que os argumentos colocam em dúvida é a realidade do mundo exterior, tal como ele é compreendido pela nova ciência, notadamente a física cartesiana, pois os princípios que são colocados em dúvida são os da filosofia natural de Descartes: espaço, tempo, movimento, número. ${ }^{21}$ Estes princípios são colocados em dúvida tanto na Primeira Meditação como em La 131 com os argumentos do sonho e do Deus enganador. O argumento do sonho na Primeira Meditação tem seu cume nas "coisas mais simples e mais universais" (do que cores e formas sensíveis): a extensão e suas propriedades (quantidade, grandeza, número, lugar e tempo), cuja existência exterior à mente é posta em dúvida pelo argumento do sonho. Pascal observa que exatamente as mesmas experiências espaço-temporais da vigília ocorrem no sonho, não havendo como distingui-las. O argumento da incerteza da nossa origem coloca sob suspeita o nosso sentimeto de verdade dos princípios da natureza, retomando os três cenários mencionados por Descartes: o do Deus bom, o do Deus enganador e o do ateísmo. ${ }^{22} \mathrm{E}$, novamente como Descartes, é o argumento da incerteza da origem que Pascal toma como a principal força dos pirrônicos, contrapondo-o à "única força dos dogmáticos" acima indicada.

Pascal utiliza um "pirronismo" que não é pirrônico, mas cartesiano, para fins alheios ao pirronismo, como o faz Descartes. Poder-se-ia perguntar por que Pascal chama tais argumentos de pirrônicos. Em primeiro lugar, não há nenhuma evidência de que Pascal tenha lido os textos dos céticos antigos. Montaigne, a quem ele toma por "pirrônico perfeito" no Entretien, não utiliza, como indicado, estes argumentos. Pascal não está interessado em apresentar posições históricas, mas reconstruções filosóficas, seguindo também neste ponto Descartes. Com efeito, Descartes não distingue sua dúvida da pirrônica nos textos que Pascal pôde ler. Na terceira parte do Discurso do Método,

enganador. Se há uma fonte de Descartes para este argumento, esta é sem dúvida escolástica, elaborada no contexto das discussões sobre a potentia absoluta de Deus. Ver: GREGORY. Dieu trompeur et malin génie, p. 293-347).

20 Trata-se, nos pirrônicos, de contrapor experiências de vigília com as do sonho para mostrar que uma não tem privilégio sobre a outra. A possibilidade de distingui-las é assim pressuposta no argumento. (Ver $\mathrm{PH}$ I. 104). Nos Acadêmicos, trata-se de mostrar a falibilidade da impressão cognitiva e não de duvidar da possibilidade de se distinguir sonho de vigília, como explicita Cícero em Ac II. 88. Curley (Descartes against the Skeptics, p. 69) indica uma semelhança com o argumento em Montaigne. Neste último, o argumento de fato se aproxima do de Descartes, mas se trata menos da impossibilidade da distinção do que de mostrar que a semelhança das experiências em sonho e vigília introduz uma desconfiança sobre o caráter epistêmico da segunda. $\mathrm{O}$ argumento não aparece em Charron.

21 A lista dos princípios visados pelos argumentos céticos é dada em La 110.

22 A hipótese ateísta em Descartes inclui três alternativas: o destino, o acaso e uma cadeia causal necessária. Pascal cita somente o acaso (AT VII 21). 
Descartes diferencia sua dúvida da dos céticos somente quanto ao fim (AT VI 29). Nas Respostas às Segundas Objeções, Descartes diz ter tido que retomar, para os seus próprios propósitos, os argumentos dos acadêmicos e céticos (AT VII 130). ${ }^{23}$ Nas Respostas às Terceiras Objeções, ele diz que utilizou os argumentos céticos sem pretender qualquer originalidade (AT VII 171-172), como se os seus argumentos fossem da mesma natureza da dos céticos antigos. Por fim, nas Notae in Programa Quoddam, Descartes se refere a "dúvidas semelhantes" dos céticos antigos (AT VIII-2 367). Somente na Entrevista com Burman, texto publicado muito depois da morte de Pascal, Descartes diz não ter se contentado, na sua dúvida, com as objeções habituais dos céticos (AT V 147).

Na maioria destas alusões aos céticos antigos, Descartes deixa clara a instrumentalização que faz da dúvida cética. Ela lhe serve basicamente para dois objetivos: preparar a distinção entre alma e corpo e permitir uma total superação da dúvida com a fundação da nova filosofia em bases indubitáveis. A instrumentalização da dúvida cética por Pascal é para outro fim. A exposição das principais forças dos pirrônicos serve não para estabelecer a distinção entre mente e corpo, e muito menos para uma fundamentação metafísica do conhecimento, mas para a construção de um impasse filosófico que mostraria a limitação da luz natural e a necessidade de se recorrer à Bíblia. Assim, enquanto em Descartes estes argumentos céticos mais fortes (mais fortes que os antigos) servem para a refutação do próprio ceticismo, em La $131 \mathrm{o}$ ceticismo permanece epistemologicamente fortalecido no campo da filosofia natural. Pascal rebate a refutação de Descartes do argumento do sonho na Sexta Meditação, dizendo que a incapacidade da memória de ligar os sonhos entre si e estes com o resto de nossa experiência seria um critério confiável da distinção, alegando a possibilidade de os sonhos concordarem e de se sonhar em companhia. ${ }^{24}$ Enfim, quanto ao argumento da incerteza da origem, enquanto Descartes crê ser possível afastar esta dúvida com as provas da existência de Deus, Pascal alega que só é possível afastá-la apelando-se para a fé e a revelação. Em Pascal, contrariamente a Descartes, o cético não pode ser vencido num terreno meramente epistemológico. Ele é vencido no terreno psicológico e moral, na medida em que não é possível manter a suspensão do juízo.

23 Descartes distingue as duas escolas do ceticismo antigo, ficando implícito que por "céticos" entende os pirrônicos, denominações equivalentes segundo Sexto Empíricico (PH I.7) e Diógenes Laércio (Vidas e Doutrinas dos Filósofos Ilustres, IX.69).

24 Mas note-se que a resposta de Descartes se situa no plano moral e não no metafísico, afastado com o argumento do Deus não enganador. 
Embora tenha sido a posição de Pascal face ao ceticismo e não a de Descartes que prevaleceu na filosofia posterior, de Hume a Russell, o uso cartesiano do ceticismo é mais correto historicamente do que o pascaliano. Contrariamente à leitura de Popkin, Descartes não parece especialmente preocupado em refutar os céticos antigos. ${ }^{25}$ Uma eventual refutação do ceticismo seria mais um ganho suplementar decorrente do sucesso do seu projeto filosófico. A dúvida visa fundamentalmente estabelecer a separação mente/ corpo, colocando em questão as coisas sensíveis/corpóreas e estabelecendo a realidade das inteligíveis. Embora a separação mente/corpo seja totalmente alheia ao ceticismo antigo, como à filosofia antiga em geral, a colocação em dúvida das coisas sensíveis é plenamente consistente com o ceticismo antigo. $\mathrm{O}$ estabelecimento das inteligíveis certamente não é consistente com o pirronismo, mas poderia ser com a nova academia se fosse dado crédito a um suposto platonismo esotérico citado em algumas fontes. ${ }^{26}$ Embora esta hipótese de um suposto platonismo secreto da nova academia seja negada pela maioria dos intérpretes contemporâneos, ela é levada a sério por Agostinho e por Simon Foucher no final do século XVII. ${ }^{27}$

Quanto à utilização pascaliana do ceticismo, como Pascal tem por projeto refutar ou mostrar a insuficiência da posição dos dogmáticos e dos céticos, deveria se restringir às posições dos céticos, seja a dos antigos, seja a dos modernos (Montaigne). Entretanto, Pascal evoca somente "as principais forças dos pirrônicos", isto é, os argumentos da dúvida hiperbólica ou metafísica de Descartes, "deixando de considerar", como ele próprio afirma em uma parte riscada do manuscrito dos Pensamentos, "as [forças] menos importantes, como os discursos contra as impressões do hábito, da educação, dos costumes dos países e outras coisas semelhantes (...) que são derrubadas pelo menor sopro dos pirrônicos". Pascal deixa, assim, de lado os argumentos dos céticos antigos (Sexto etc.), renascentistas (Montaigne, Charron) e seus contemporâneos (La Mothe Le Vayer), muito embora quem "[olhasse] os seus livros (...) depressa [ficaria persuadido] e talvez demais". Os argumentos dos pirrônicos de carne e osso, embora certamente menos fortes do que os

25 Ver: POPKIN. História do Ceticismo de Erasmo a Spinoza, capítulo IX: "Descartes: Conquistador do Certicismo". A interpretação contrária é defendida por Thomas Lennon, que a apresentou em um curso lecionado no Departamento de Filosofia da UFMG em 2002. Os argumentos de Lennon aparecerão em um livro em preparação sobre Descartes, Huet e o ceticismo.

26 SEXTO EMPÍRICO, PH I. 234; e CíCERO, Ac II. 60.

27 É assim que Foucher considera Descartes um acadêmico, mas até certo ponto, a saber, enquanto estabeleceu verdades puramente inteligíveis, pois segundo Foucher Descartes cai num dogmatismo ao pretender um conhecimento certo do mundo material. Ver: MAIA NETO. Foucher's Academic Cartesianism, p. 71-95. 
hiperbólicos de Descartes, são por isso mesmo mais plausíveis e praticáveis. Parecendo favorecer os pirrônicos ao reter somente suas principais forças, Pascal de fato retira os argumentos do sonho e do Deus enganador do seu contexto próprio metafísico em Descartes e aponta o fato de não serem praticáveis como evidência da inviabilidade da posição cética. O resultado é um divórcio entre ceticismo e vida prática, o ceticismo ficando imbatível no terreno meramente epistemológico, mas, contrariamente à intenção cética, totalmente ineficaz do ponto de vista moral. ${ }^{28}$

Ao retomar os argumentos da dúvida cartesiana sobre o mundo exterior e recusar a solução cartesiana desta dúvida, Pascal contribui de forma decisiva para a configuração do "Descartes septique malgré lui", para citar o capítulo da História do Ceticismo no qual Richard Popkin examina a leitura cética que se começa a fazer - ou se derivar - de Descartes antes mesmo de sua morte. ${ }^{29}$ Esta apropriação cético-epistemológica da instrumentalização do ceticismo operada por Descartes é marcante em Hume, por exemplo, que foi bastante influenciado - positiva e reativamente - por Pascal. ${ }^{30} \mathrm{~A}$ segunda parte deste artigo estabelece um outro caminho pelo qual o ceticismo moderno ou cartesiano foi construído: através de Pierre-Daniel Huet. Embora Huet tenha sido relegado às margens da filosofia, foi bastante influente no final do século XVII e início do XVIII. ${ }^{31}$ Mostro a seguir que Pascal contribui significativamente para a elaboração do Descartes cético huetiano.

Pierre-Daniel Huet foi provavelmente o maior erudito francês do século XVII. Foi também cientista experimental, tendo estabelecido a primeira academia de ciências no interior da França (em Caen). Embora inicialmente influenciado por Descartes, veio a se tornar o mais eminente e influente crítico desse filósofo no final do século XVII, reagindo contra os cartesianos de sua época e, em particular, ao desprezo que estes, especialmente Malebranche, manifestavam pela erudição. ${ }^{32} \mathrm{O}$ livro que Huet escreveu contra Descartes, a Censura Philosophiae Cartesianae (Paris, 1689), fazia parte de uma obra

28 Ver: MAIA NETO. Charron's epoché and Descartes' cogito: the skeptical base of Descartes' refutation of skepticism, p. 81-113.

29 POPKIN. História do Ceticismo de Erasmo a Spinoza, p. 301-330.

30 Ver: MAIA NETO. Pascal and Hume: Pyrrhonism versus Nature, p. 41-49.

31 Hume, por exemplo, cita Huet nos Diálogos sobre a Religião Natural.

32 Esta tese, que me parece bastante plausível, é defendida por Thomas Lennon como explicação do anticartesianismo de Huet. Ver: LENNON. Huet, Malebranche and the birth of skepticism, p. 149-165. 
maior, que foi fatiada em decorrência da oposição sofrida por Huet ao ceticismo da sua primeira parte, que por esta razão só veio a ser publicada postumamente sob o título de Traité Philosophique de la Foiblesse de l'Esprit Humain (Amsterdam, 1723). ${ }^{33}$

O Traité Philosophique apresenta, na sua primeira parte, treze provas da fraqueza do entendimento humano, isto é, da impossibilidade, como afirma o título desta parte, "da razão poder conhecer a verdade com uma certeza inteira e perfeita". A nona prova, que compõe o capítulo 10 do livro I, é a "razão de duvidar de todas as coisas, proposta por Descartes, a saber, que ignoramos se Deus não nos criou com uma natureza tal que nos enganamos sempre" (p. 85). Podemos dizer que este argumento é para Huet, como para Pascal, uma "das principais forças dos pirrônicos". Com efeito, Huet diz que, dentre todas as provas citadas, é "principalmente esta razão de duvidar de todas das coisas que Descartes propôs" (p. 87) que liquida com o último recurso dos dogmáticos, ao qual recorrem para evitar o dilema imposto pelos pirrônicos entre um regresso ao infinito e um círculo vicioso, a saber, a alegação da auto-evidência de princípios ou noções. ${ }^{34}$

O manuscrito de uma versão primitiva do Traité que encontrei na Biblioteca Nacional em Paris, ainda figurando como a primeira parte da grande obra abortada, permite estabelecer as modificações que Huet fez no texto, muitas das quais em função de críticas de amigos íntimos a quem mostrou o manuscrito. O capítulo nove com a dúvida cartesiana do Deus enganador foi um dos mais alterados, tendo Huet feito o seguinte acréscimo no ponto em que afirma ser tal dúvida "digna de um filósofo". "Quando digo que ela é digna de um Filósofo, não quero dizer um Filósofo Cristão, que sabe que Deus esclarece todos os homens que vêm a este mundo (Job I.9). Mas Descartes falava então como Filósofo, e não como Cristão" (p. 85-86, o itálico indica o acréscimo feito por Huet no manuscrito).

33 Há uma edição fac-símile desta edição, publicada pela Olms em 1974. As citações a seguir são desta edição. Em uma das minhas missões de trabalho em Paris e Caen, no quadro do projeto CAPES-COFECUB, descobri o que deve ser uma das primeiras versões do manuscrito do Traité Philosophique, precedido de um sylabus detalhando todos os livros e capítulos desta grande obra, na qual o Traité figurava como o primeiro livro. Esta obra, cujo titulo era Quaestiones Alnetanae, começava então com uma dissertação sobre a fraqueza do entendimento humano (livro I), incapaz de alcançar uma certeza indubitável, continuava no livro II, exemplificando esta fraqueza com o exame da filosofia cartesiana, em seguida dissertava sobre as relações entre a razão e a fé (livro III), argumentando a necessidade de a primeira subordinar-se à segunda, e concluía com uma apologética do cristianismo através de uma exegese erudita comparativa entre os ritos cristãos e pagãos (livro IV), e entre a moral cristã e a pagã (livro V), em ambos os casos mostrando como os ritos e as éticas pagãs são cópias ou têm por origem a doutrina cristã. Somente estes três últimos livros foram publicados sob o título Quaestiones Alnetanae em Caen em 1690.

34 Huet faz referência aqui e em outros capítulos aos 5 modos dos pirrônicos. Ver: SEXTO EMPÍRICO, PH I. 164-177; e DIÓGENES LAÉRCIO, Vidas IX. 88-89. 
Esta surpreendente defesa de Descartes por Huet, mas notem bem, de um Descartes cético, pode ser esclarecida graças à recente publicação de duas cartas de dois destes amigos a quem Huet mostrou o manuscrito e solicitou críticas: o jesuíta Louis Le Valois e Jean-Baptiste du Hamel. ${ }^{35}$ Le Valois é um anticartesiano ferrenho, que publicou sob o pseudônimo de Louis de La Ville o livro Sentimens de M. Descartes touchant l'essence et les proprietez du corps, opposez a la doctrine de l'Eglise, et conforme aux erreurs de Calvin, sur le sujet de l'Eucharistie (Paris, 1680). Le Valois é curto e grosso a propósito da retomada por Huet do argumento cartesiano do Deus enganador: "O nono argumento, que é de Descartes, me parece chocante. Meu espírito não o domestica." ${ }^{36}$ Du Hamel, ex-membro da Oratória, também crítico, mas bem mais receptivo do que Le Valois a Descartes e ao cartesianismo, ${ }^{37}$ rejeita igualmente o argumento. Sua crítica foi provavelmente o que levou Huet a acrescentar a defesa de Descartes acima citada. Segundo Du Hamel,

Isto que diz Descartes não pode concordar com a verdadeira idéia de Deus, que é a verdade mesma, e quem não pode nos ter criado nesta necessidade de nos enganar. Você acrescenta que esta é uma dúvida digna de um filósofo. Não sei se esta dúvida é digna de um filósofo: mas não creio que um Cristão possa ter esta dúvida, [a saber] se Deus não nos criou com o desígnio de sempre nos enganarmos, e até nas coisas que nos parecem as mais evidentes. Ele [Descartes] deveria ao menos resolver suas dúvidas e assim eu não gostaria de aprovar esta ficção de Descartes. ${ }^{38}$

Du Hamel começa o seu comentário citando um manuscrito de um doutor não especificado, que teria mostrado que "este princípio do senhor Descartes, que é necessário uma vez na vida duvidar de tudo, é perigoso, pois ele desvia nosso espírito da visão de Deus, para ocupá-lo da investigação das criaturas" (p. 173), ou seja, o contrário do que afirma Descartes na dedicatória das $\mathrm{Me}$ -

35 Du Hamel, amigo de longa data de Huet, figurava como um dos interlocutores das Quaestiones Alnetanea, obra concebida como um diálogo. Huet fala assim de Du Hamel em suas Memórias: "Je ne vis jamais de plus excellent homme, d'âme plus candide, ni, après qu'il voulut bien être de mes amis, d'ami plus fidèle. Ce qu'il pensait de moi, il l'a bien fait voir dans ses écrits, qui sont nombreux et ont été fort utiles aux Lettres" [Jamais vi homem mais excelente, de alma mais cândida e, depois que tornou-se um dos meus amigos, mais fiel. Os seus escritos - que são numerosos e muito úteis para as Letras - mostram bem o que ele pensava de mim]. (Mémoires, p. 85).

36 Le Valois diz que o seu espírito não aprivoise o argumento cartesiano. Em uma tradução literal: não o consegue domar. Ver a carta de Le Valois a Huet com comentário sobre os dois primeiros livros da obra original planejada por Huet, publicada por Elena Rapetti, Percorsi Anticartesiani nella Lettere a PierreDaniel Huet, p. 74. Rapetti data esta carta de dezembro de 1685 a janeiro de 1686.

37 Du Hamel buscava conciliar a filosofia antiga (Platão, Aristóteles e Epicuro, com a nova, sobretudo a de Descartes). Ver seus livros De consensu veteris et novae philosophiae (Paris, 1663) e Philosophiae vetus et nova ad usum scholae accomodata (Paris, 1678).

38 Du Hamel comenta detalhadamente os 3 primeiros livros da obra abortada em carta de 24 de julho de 1689. A crítica citada está em RAPETTI, Percorsi Anticartesiani nella Lettere a Pierre-Daniel Huet, p. 180. 
ditações à Faculdade de Teologia da Sorbonne. A posição de Huet segundo Du Hamel é ainda mais perigosa do que a de Descartes, "pois, isto que diz Descartes, que para o exame da verdade é bom colocar tudo em dúvida uma vez na vida, os Céticos, que você defende, gostariam que o fizéssemos sempre" (p. 173)..$^{39}$ Du Hamel afirma ainda que o remédio de Huet contra a arrogância da razão é excessivo - bastaria limitá-la para conciliá-la com a fé - e contraproducente, pois tal ataque à razão atinge também a própria fé.

Certamente estas reações de Le Valois e, sobretudo, de Du Hamel pesaram bastante na decisão de Huet de não publicar o Traité philosophique em vida e motivaram várias das modificações que fez nesta obra, por exemplo, o acréscimo no capitulo 10 já citado e um semelhante, no capítulo 15 do livro III, livro em que responde a objeções levantadas aos argumentos céticos do livro I. No caso da objeção contra o argumento do Deus enganador, Huet acrescenta ao manuscrito original: "caberia a Descartes responder a esta Objeção (que a hipótese é ímpia), pois é o Autor do argumento, que somente relatei, sem aprová-lo, uma vez que nossa santa Religião nos ensina outra coisa” (p. 269). Entretanto, Huet não só relata como aprova o argumento. Diz que Descartes poderia replicar, entre outras coisas, que Deus nos deixou um meio de evitar todo o erro, mesmo nos criando naturalmente incapazes da verdade: o poder de suspendermos o juízo (p. 269-272). Huet apresenta um Descartes cético, desenvolvendo justamente a alternativa cética somente aludida por Descartes no início da Segunda Meditação, ${ }^{40}$ e justificando a legitimidade filosófica da dúvida cartesiana mesmo por um cristão. ${ }^{41}$ Huet aparece assim quase um cartesiano frente a estes críticos, mas um cartesiano cético, que rejeita a parte construtiva metafísica de Descartes, ficando somente com a dúvida e outras doutrinas cartesianas passíveis de desdobramentos céticos. ${ }^{42}$

Este Descartes cético não deriva somente da leitura que Huet fez do corpus cartesiano. Embora cite os principais textos de Descartes sobre a dúvida

39 Agostiniano, quando Du Hamel fala do ceticismo tem em mente os novos acadêmicos. Ver o Contra Acadêmicos e outras obras, nas quais Agostinho se refere aos acadêmicos. Entretanto, este contraste entre a dúvida provisória de Descartes e a definitiva dos céticos provavelmente tem origem na própria distinção feita por Descartes no Discurso do Método. (AT VI 29).

40 "Tudo que admitir a menor dúvida deixarei de lado como se fosse completamente falso e continuarei nesta via até encontrar algo certo, ou, se nada mais, até pelo menos reconhecer como certo que não há nada certo" (AT VII 24).

41 Dois outros argumentos que segundo Huet Descartes "não deixaria de dar aos objetores" são os seguintes. Primeiro um argumento ad hominem: o objetor precisa reconhecer que nos enganamos às vezes, e como isto não faz de Deus um enganador para o objetor, logo também não o faz se nos enganamos sempre. Segundo, Deus não nos obriga a crer que somos capazes da verdade, logo não é enganador.

42 Em particular a segunda prova de Descartes, que se vale da fisiologia e das idéias sensíveis em Descartes. Ver livro I, capítulos 3 e 9. 
hiperbólica, ${ }^{43}$ é de Pascal - especialmente de La 131 (o fragmento sobre as principais forças dos pirrônicos) e La 110, este contra os pirrônicos que os editores de Port-Royal inseriram em La 131 na tentativa de balancear as forças de pirrônicos e dogmáticos - que Huet retira sua apropriação cética da dúvida cartesiana. É possível comprovar que coincidências textuais entre o capítulo 10 do livro I do Traité philosophique e os fragmentos La 131 e 110 dos Pensées têm origem na leitura anotada por Huet em um exemplar da edição de 1670 de Port-Royal, leitura feita pouco antes ou na ocasião mesma em que trabalhou na composição do que veio a ser o Traité..$^{44}$

Como indicado acima, Huet articula o argumento da incerteza da nossa origem com os cinco modos do pirronismo antigo. $\mathrm{O}$ argumento cartesiano seria o golpe final que atingiria a última trincheira na qual se refugia o dogmático quando pressionado pelo pirrônico a justificar sua doutrina, ao tentar evitar tanto um regresso ao infinito (segundo modo) quanto um círculo vicioso (quinto modo). A única alternativa a este dilema segundo o pirrônico é a alegação pelo dogmático de que a doutrina em exame precisa ser aceita sem justificação ulterior, ao que o pirrônico responde com o modo da hipótese (quarto modo), alegando seu igual direito de afirmar, sem justificar, a doutrina contrária e assim reestabelecer a eqüipolência. ${ }^{45} \mathrm{O}$ modo da hipótese é tratado no pirronismo antigo somente como um problema de autoridade, sem que o pirrônico apresente uma resposta à pretensão por parte dos dogmáticos de que as proposições não justificadas por outras proposições são princípios autojustificáveis ou evidentes. Huet se vale do argumento da incerteza da origem para responder a esta alegação, justificando o modo pirrônico da hipótese. Embora Pascal não faça esta articulação, ao menos de forma explícita, entre o argumento da incerteza da origem e os cinco modos do pirronismo, não deixa de preparar o terreno para o reforço huetiano do modo da hipótese. Em primeiro lugar, ao indicar que o que o argumento busca colocar em dúvida é justamente a verdade dos principios. ${ }^{46}$ Em segundo lugar, ao fazer a evidência

43 Huet cita os artigos 5 e 13 da primeira parte dos Princípios e a Primeira e a Sexta Meditações.

44 Huet trabalhou na redação do Traité entre 1680, quando passa a residir em Aunai, e 1685, quando envia o texto a Louis Le Valois. As anotações de Huet em seu exemplar dos Pensées foram pela primeira vez publicadas por Raymond Francis, Les Pensées de Pascal en France de 1841 a 1942 (Paris: A. G. Nizet, 1959), p. 381-388. Francis indica uma leitura posterior a 1675, data de uma edição das Trois Veritez de Charron citada por Huet. Para um estudo comentado destas anotações, incluindo uma análise dos traços marginais e sublinhados por Huet nos Pensamentos de Pascal, ver: MAIA NETO; POPKIN. Bishop PierreDaniel Huet's Remarks on Pascal, p. 147-160. Ver, também, de Antony McKenna, "Pascal et Huet" p. 135142; e De Pascal á Voltaire. Le rôle des Pensées de Pascal dans l'histoire des idées entre 1670 et 1734, v. I, p. 316-327.

45 Ver PH I. 164-174.

46 Estes princípios são os princípios da física cartesiana (tempo, espaço, movimento, número). Embora o argumento na Primeira Meditação coloque estas naturezas simples em dúvida, o foco central são as 
destes princípios depender de um sentimento de uma natureza cuja veracidade depende da determinação de sua origem. Enfim, e principalmente, pois aqui temos a inovação cética que Pascal introduz no argumento cartesiano, a convicção de que a determinação da origem não pode ser feita, como diz Huet no Traité "se a Razão não se vale do auxílio da fé" (p. 87). A incapacidade da razão de resolver esta dúvida e a necessidade do recurso à revelação cristã corrobora a tese fundamental de Huet sobre a fraqueza do entendimento humano e a necessidade da fé para se obter uma certeza mais do que apenas moral, uma certeza metafísica. O Traité philosophique, que estabelece a faiblesse de l'esprit humain, se complementa, em Huet, com o estabelecimento da força da fé, como consta no título de um manuscrito autógrafo do Traité descoberto por Popkin na Holanda. ${ }^{47}$

No exemplar dos Pensées anotado por Huet, podemos verificar que ele assinala todas as ocasiões em que Pascal afirma a impossibilidade de determinar a nossa origem - e, portanto, a certeza dos princípios - "hors la foi" ("fora da fé")..$^{48}$ Vai neste mesmo sentido o interesse particular que Huet demonstra por duas passagens do fragmento La 110 que os editores incorporaram ao La 131. Onde Pascal diz que "Nous savons que nous ne revons point, quelque impuissance où nous soyons de le prouver par la raison", Huet grifa a continuidade da passagem: "Cette impuissance ne conclut autre chose que la faiblesse de notre raison" [Esta impotência não conclui outra coisa exceto a fraqueza da nossa razão], sem grifar a conclusão antipirrônica do parágrafo: "mais non pas l'incertitude de toutes nos connaissances, comme ils [os pirrônicos] le prétendent" [mas não a incerteza de todos os nossos conhecimentos,

verdades matemáticas que não são mencionadas neste contexto nem por Pascal nem por Huet, o que corrobora a hipótese de Pascal, e não Descartes, ser a fonte imediata de Huet.

47 Popkin descobriu um manuscrito autógrafo do Traité na Holanda, cujo título é "Traité philosophique de la foiblesse de l'esprit human et de la force de la foi". Por alguma razão "a força da fé" não figura no título da obra publicada postumamente na Holanda, o que certamente contribuiu para o escândalo que ela causou. Recordo que o plano original de Huet era no primeiro livro (que virou o Traité), mostrar esta fraqueza da razão, no segundo (que virou a Censura), exemplificá-la no exame crítico do cartesianismo, no terceiro mostrar a condição em que fé e razão podem se articular, qual seja, pela submissão da segunda à primeira, e enfim, no quarto e quinto, a apologia cristã histórica-erudita compatível com esta relação entre razão e fé.

48 Coloco em itálico as passagens sublinhadas por Huet: "Les principales raisons des Pyrrhoniens sont que nous n'avons aucune certitude de la vérité des principes, hors la foi et la révélation sinon ...." [As principais razões dos pirrônicos são que nós não possuimos nenhuma certeza da verdade dos princípios, fora da fé e da revelação se não que (...)]. "Or ce sentiment naturel n'est pas une preuve convaincante de leur vérité; puisque n'y ayant point de certitude hors la foi, si l'homme est créé par un Dieu bon, ou par un démon méchant (...)" [Mas este sentimento natural não é uma prova convincente da verdade [dos princípios], pois não havendo nenhuma certeza fora da fé se o homem foi criado por um Deus bom ou por um demônio mal(...)] "De plus, que personne n'a d'assurance, hors la foi, s'il veille ou s'il dort(...)" [Além disto, ninguém está assegurado, fora da fé, se vela ou dorme(...)] (p. 159) "Et cependant, depuis un si grand nombre d'annés, jamais personne sans la foi n'est arrivé (ao bem)" [Entretanto, depois de tantos anos, ninguém sem a fé alcançou o bem] (p. 164). 
como eles [os pirrônicos] pretendem] (p. 161, grifos de Huet). Um pouco adiante, no texto de Pascal, Huet assinala: "Cette impuissance ne peut donc servir qu'à humilier la raison qui voudrait juger de tout" [Esta impotência só pode portanto servir para humilhar a razão que gostaria de tudo julgar] (ênfase de Huet), sem assinalar a continuação da frase de Pascal: "mais non pas à combattre notre certitude, comme s'il n'y avait que la raison capable de nous instruire" [mas não para combater nossa certeza, como se só a razão fosse capaz de nos instruir] (p. 162). Em ambos os casos, Huet assinala as frases de Pascal sobre a fraqueza da razão, mas não as que afirmam, contra os pirrônicos, a certeza das verdades. Se Pascal já faz uma utilização mais cética da dúvida cartesiana do que Descartes, Huet faz uma utilização ainda mais cética desta mesma dúvida por Pascal, sobretudo mais cética do que a utilização mais dogmática do Pascal da edição de Port-Royal. ${ }^{49}$

Huet rejeita a única força que Pascal concede aos dogmáticos, a saber, que, embora a razão seja incapaz de justificar racionalmente os princípios, não é possível apagar o sentimento de verdade e, por conseguinte, suspender o juízo de boa-fé. Isto para Pascal é evidência da fraqueza da razão, e neste ponto Huet é - como os céticos antigos - mais racionalista do que Pascal. A razão é fraca para estabelecer princípios (como em Pascal), mas ela é forte o suficiente para colocá-los em dúvida. Uma das únicas notas marginais desta seção (fora notas de referência) é outra surpreendente defesa de Descartes, mas, como no caso da anterior, de um Descartes cético, mais cético do que o próprio Pascal. No ponto culminante da contraposição entre o dogmático e o "pirrônico", em que Pascal mostra a fraqueza deste último, incapaz de exercer uma dúvida radical, "Doutera-t-il de tout? Doutera-t-il s'il veille, si on le pince, si on le brûle? Doutera-t-il s'il doute? Doutera-t-il s'il est? On n'en saurait venir là: et je mets en fait qu'il n'y a jamais eu de Pyrronien effectif et perfait" [Duvidará ele de tudo? Duvidará que está acordado se o picamos ou queimamos? Duvidará se duvida? Duvidará se existe? Não se pode chegar a tal extremo. Jamais existiu um pirrônico efetivo e perfeito] (p. 163), Huet assinala a frase em itálico e anota na margem: "M. Des Cartes, tout dogmatique qu'il est, a enseigné qu'il fallait commencer par ce dou(te) philosoph(ique)" [Descartes, embora dogmático, ensinou que era preciso começar por esta

49 Os editores de Port-Royal substituiram o conhecimento "du cœur" [do coração] de Pascal por "de sentiment et d'intelligence" [de sentimento e de inteligência], num caso eufemisticamente: "par sentimente et par une intelligence vive et lumineuse" [pelo sentimento e por uma inteligência viva e luminosa]. Tais acréscimos derivam, provavelmente, do mesmo intuito que motivou a inserção de La 110 em La 131, a saber, reforçar a única força dos dogmáticos segundo Pascal e assim tentar estabelecer um certo equilíbrio entre pirrônicos e dogmáticos, equilíbrio exigido pelo argumento mesmo da verdadeira religião. 
dúvida filosófica] (p. 163). O quê? Descartes pirrônico efetivo e perfeito para Huet? Sim, o Descartes da Primeira Meditação. Foi através de Descartes que Huet conheceu a dúvida (ele conheceu os céticos antigos bem depois). ${ }^{50}$

Huet deu continuidade ao caminho filosófico da dúvida inciado por Descartes (mas como vimos, com intenções bem diferentes das de Descartes), mas lamentavelmente, segundo Huet, abandonado já na Segunda Meditação. ${ }^{51}$ Evidentemente Huet desconsidera, propositadamente ou não, que a dúvida cartesiana é hiperbólica, que Descartes sabe bem que tal dúvida radical é insustentável na prática. Pascal se vale justamente deste caráter hiperbólico da dúvida cartesiana para argumentar que os "pirrônicos" não conseguem se sustentar no ponto em que são mais fortes. A leitura huetiana do Descartes cético passa pela desconsideração dos propósitos da dúvida cartesiana - estabelecer a distinção real entre a alma e o corpo e produzir um fundamento certo do conhecimento -, assim como a leitura cartesiana da dúvida cética passa pela desconsideração dos propósitos próprios desta dúvida. O propósito de Pascal é diferente tanto do de Descartes como do de Huet. O seu propósito é estabelecer a insuficiência do dogmatismo (destruído pela dúvida cartesiana) e do pirronismo (destruído pela inviabilidade prática desta dúvida) para demonstrar a fraqueza e insuficiência de toda filosofia, por um lado (inclusive a cética), e a força e excelência cognitiva da revelação cristã, por outro. O propósito de Huet é bem diferente do de Pascal. É mostrar a fraqueza da razão humana no que concerne ao estabelecimento de verdades, inclusive da verdade da própria doutrina revelada. Este é um ponto de discordância fundamental de Huet em

50 Huet tomou conhecimento da filosofia cartesina enquanto era um brilhante estudante no colégio jesuíta de Caen, na ocasião da publicação dos Princípios, em 1647. Na sua biografia intelectual, relata o impacto que sofreu. "Descartes publia dans ce temps-là les principes de sa secte et comme durant les trois années précédents j'avais fort cultivé la philosophie et m'étais pénétré de ses préceptes et ses dogmes, j'eus un violent désir de connaître ceux de Descartes et je n'eus pas de cesse que je ne me procurasse son livre et ne le parcourusse en diligence. II me serait difficile de dire quel enthousiasme excitèrent en moi, jeune encore et ne sachant rien des anciennes sectes philosophiques, la nouveauté de cette méthode et ces merveilles éblouissantes issues des principes les plus simples et les plus clairs" [Descartes publicou nesta época os princípios de sua seita. Como nos três anos anteriores eu havia cultivado bastante a filosofia e me deixado penetrar pelos seus preceitos e dogmas, tive um forte desejo de conhecer os de Descartes. Não descansei antes de encontrar o seu livro e o percorrer com atenção. Seria difícil dizer o entusiasmo que me causou, ainda jovem e nada sabendo das seitas antigas da filosofia, a novidade do seu método e as maravilhas retiradas de princípios tão claros e tão simples] (HUET. Mémoires, p. 16).

51 Neste mesmo capítulo 10 do livro do Traité, onde Huet cita a dúvida cartesiana, afirma que "lors qu'il [Descartes] se porte pour nouvel inventeur de la Vérité, ayant commencé le Systême de sa Philosophie par le doute, \& ayant proposé les raisons de ce doute; néanmoins incontinent après comme si le chemin de la Vérité lui avoit été montré du Ciel, il cesse si absolument de douter, qu'il ne se met pas seulement en peine de resoudre les argumens qui l'avoient obligé de douter" [quando Descartes se coloca como novo inventor da Verdade, tendo começado o Sistema de sua Filosofia pela dúvida, e tendo proposto as razões desta dúvida, entretanto, logo em seguida, como se a Verdade lhe tivesse sido revelada do Céu, ele cessa tão absolutamente de duvidar, que sequer se preocupa em resolver os argumentos que o haviam obrigado a duvidar] (p. 86). Ver, também, Censura Philosophia Cartesianae (Paris, 1689), capítulo 1, parágrafo 14. 
relação a Pascal, certamente uma das razões por que rejeita qualquer força dos dogmáticos e qualquer fraqueza dos céticos.

Duas razões impedem Huet de aceitar o argumento da verdadeira religião de Pascal. A primeira diz respeito às diferentes maneiras pelas quais Huet $\mathrm{e}$ Pascal concebem a relação entre razão e fé. Embora Pascal considere, como Huet, que o cristianismo não pode ser provado pela razão, embora ambos mantenham um distanciamento crítico da teologia natural, Pascal não é fideísta como Huet. Os argumentos pascalianos não se reduzem às provas históricas baseadas nas profecias e milagres. Pascal elabora também o argumento da verdadeira religião ou prova pela doutrina, que, embora não demonstre a verdade do cristianismo, atribui-lhe um poder explicativo racional. Huet nega esta atribuição de poder explicativo à revelação, considerando, contrariamente à visão bem mais sofisticada de Pascal sobre a relação da razão com a fé, que tal atribuição implica a submissão da fé à razão. ${ }^{52}$ Em suas anotações nas margens dos Pensées, Huet recusa a afirmação de Pascal de que o cristianismo com a doutrina da queda é a única religião capaz de explicar e conciliar as contradições humanas. ${ }^{53}$ Huet rejeita o argumento da verdadeira religião, pois não vê na doutrina do pecado original nada de original, no sentido de não encontrável em outras religiões e filosofias, embora veja nela originalidade, no sentido de ser a origem histórica de todas as outras. Mas aí, neste caso, a tarefa apologética é provar esta disseminação do Velho Testamento pelas demais religiões e filosofias através de um trabalho histórico e erudito, até mesmo arqueológico, de escavação do conteúdo original judaico por trás de manifestações pagãs. Para Huet, o cristianismo é verdadeiro não por ser a

52 Huet escreve o seguinte comentário na seção $\mathrm{V}$ do seu exemplar da edição dos Pensamentos de PortRoyal: "Soumission et usage de la raison": "Il suppose que cette soumission même dépendre de la raison: et il me semble au contraire que, de soumettre la raison à la foi, est plutôt l'ouvrage de la foi que de la raison; parce que la raison et la foi sont également impérieuses, et que, l'une ne consentira jamais d'être soumise à l'autre, et si elle l'est ce sera involontairement par violence, et par contrainte. Or, l'un des deux devant vaincre l'autre, il appartient à la foi de soumettre la raison, et non pas à la raison de soumettre la foi." [Uso e submissão da razão: Ele supõe que esta submissão depende da razão. Parece-me, ao contrário, que a submissão da razão à fé é mais obra da fé do que da razão, pois a razão e a fé são igualmente imperiosas. Uma jamais aceita se submeter à outra. Se se submeter será involuntariamente, por meio da violência. Ora, como uma das duas deve vencer a outra, cabe à fé submeter a razão e não à razão submeter a fé] Falta a Huet a visão mais refinada da razão e da fé de Pascal, para quem há a submissão total de uma razão filosófica pretensiosa, mas esta submissão está de acordo com uma outra razão, uma razão científica, experimental, não metafísica.

53 Huet anota à margem de La 617 no qual, entre outros fragmentos, Pascal afirma a unicidade do cristianismo pela sua doutrina do pecado original, única, portanto, a fornecer o diagnóstico e a profilaxia do problema moral do homem. "Cela n'est pas vrai. La Morale des Grecs et des Romains, qui était fondée sur leur religion et qui en faisait une partie, ne défend rien si sévèrement. Voyez Platon et Aristote, et Cicéron dans ses Offices, et principalement Marc Aurèle." [Isto não é verdade. A moral dos gregos e dos romanos, que era fundada em sua religião e da qual fazia parte, nada proibia tão severamente]. 
única verdadeira religião, mas ao contrário, porque se reproduz - embora imperfeitamente - em todas as outras religiões.

A segunda razão da rejeição por Huet do argumento pascaliano da verdadeira religião está no fato de não conceber o ceticismo como o aspecto epistemológico da depravação humana em decorrência do pecado original, ${ }^{54}$ tanto por que veria nesta concepção uma intrusão indevida da razão no terreno da fé, como por não compartilhar do anti-humanismo jansenista. ${ }^{55}$ Huet é um humanista, tanto no sentido do trabalho erudito que desenvolveu ao longo de sua vida, como no sentido da antropologia filosófica. Com efeito, Huet poderia ter dito de Pascal o que diz de La Rochefoucould. "Esta busca dos defeitos do homem corrompido, que [La Rochefoucould] fez com tanta sagacidade, não é feita com suficiente eqüidade. Ele às vezes não faz justiça a este homem que ele condena e que faz passar por mais corrompido do que de fato é (...) tomando como más inclinações e ações inocentes. ${ }^{~} 56$ Este mesmo humanismo (nos dois sentidos do termo), aliado à incapacidade de Huet de perceber a genialidade científica e filosófica de Pascal (compreensível para alguém do século XVII), explicaria a avaliação geral que Huet fez dos Pensamentos: "Dans tout cet ouvrage il n'y a presque rien de nouveau que l'expression, le tour, et la disposition.” [Em toda esta obra quase não há novidade, exceto a expressão, a forma e a disposição]. Avaliação injusta, considerando que La 131, sobre as principais forças dos pirrônicos, é uma fonte crucial da leitura cética da dúvida cartesiana, a começar pela leitura feita pelo próprio Huet.

\section{Referências Bibliográficas}

BELIN, C. L'Euvre de Pierre Charron 1541-1603. Littérature et théologie de Montaigne à Port-Royal. Paris: Honoré Champion, 1995.

BOLZANI FILHO, R. Acadêmicos versus Pirrônicos. Tese (Doutorado), Departamento de Filosofia da USP, São Paulo, 2003.

CARRAUD, V. Pascal et la Philosophie. Paris: PUF, 1992.

CÍCERO, M. T. Academics. Trad. H. Rackham. Cambridge, MS: Harvard University Press, 1933. (Loeb Classical Library)

CURLEY, E. Descartes against the Skeptics. Cambridge, MS: Harvard University Press, 1979.

54 Contraponho-me aqui à interpretação de Jean-Louis Quantin, "La Raison, la Certitude, la Foi: quelques remarques sur les préliminaires de l'acte de foi selon Huet", p. 83-97.

55 Huet se opôs ao jansenismo, mas sem o fervor exibido por alguns dos seus amigos jesuítas.

56 HUET. Huetiana (Amsterdam, 1722), p. 250. 
DESCARTES, R. René Descartes Euvres. Ed. Charles Adam e Paul Tannery Paris: Vrin, 1974-1986.

DIÓGENES LAÉRCIO. Vidas e doutrinas dos filósofos ilustres. Trad. Mário da Gama Kury. Brasília: EdUnB, 1985.

DU HAMEL, J-B. De consensu veteris et novae philosophiae. Paris, 1663.

Philosophiae vetus et nova ad usum scholae accomodata. Paris, 1678.

FRANCIS, R. Les Pensées de Pascal en France de 1841 à 1942. Paris: A. G. Nizet, 1959.

GREGORY, T. Dieu trompeur et malin génie. In: . Genèse de la raison classique de Charron à Descartes. Paris: PUF, 2000.

HUET, P-D. Traité Philosophique de la Foiblesse de l'Esprit Humain. Hildesheim: Olms, 1974. (Fac-símile da edição de Amsterdam de 1723).

. Censura Philosophiae Cartesianae. Hildesheim: Olms, 1971. (Fac-símile da edição de Paris de 1689).

. Alnetanea quaestiones de concordia rationis et fidei. Paris: Moelle, 1690.

. Huetiana. Paris: J. Estienne, 1722.

Mémoires. Toulouse: Société de Littératures Classiques, 1993.

IOPPOLO, A. M. Opinione e Scienza. Il debattio tra Stoici e Academici nel III e nel II secolo a c. Nápolis: Bibliopolis, 1986.

LENNON, T. Huet, Malebranche and the birth of skepticism. In: PAGANINI, G. (Ed.) The Return of Skepticism from Hobbes and Descartes to Bayle. Dordrecht: Kluwer, 2003. p. 149-165.

LE VALOIS, L. Sentimens de M. Descartes touchant l'essence et les proprietez du corps, opposez a la doctrine de l'Eglise, et conforme aux erreurs de Calvin, sur le sujet de l'Eucharistie. Paris, 1680.

LIMBRICK, E. Métamorphose d'un philosophe en théologien. In: BLUN, C. (Ed.). Montaigne. Apologie de Raymond Sebond. De la Theologia à la Théologie. Paris: Honoré Champion, 1990. p. 229-46.

MAIA NETO, J. R. The Christianization of Pyrrhonism: Skepticism and Faith in Pascal, Kierkegaard and Shestov. Dordrecht: Kluwer, 1995.

Foucher's Academic Cartesianism. In: LENNON, T. (Ed.). Cartesian Views. Papers presented to Richard A. Watson. Leiden: Brill, 2003. p. 71-95.

. Charron's epoché and Descartes' cogito: the skeptical base of Descartes' refutation of skepticism. In: PAGANINI, G. (Ed.). The Return of Skepticism from Hobbes and Descartes to Bayle. Dordrecht: Kluwer, 2003. p. 81-113. 1991.

Pascal and Hume: Pyrrhonism versus Nature. Hume Studies, 17, p. 41-49,

MAIA NETO, J. R.; POPKIN, R. H. Bishop Pierre-Daniel Huet's Remarks on Pascal. British Journal for the History of Philosophy, 3, p. 147-160, 1995.

MCKENNA, A. Pascal et Huet. XVII Siècle, 147, p. 135-142, 1985.

. De Pascal à Voltaire. Le rôle des Pensées de Pascal dans l'histoire des idées entre 1670 et 1734. Oxford: The Voltaire Foundation at the Taylor Institute, 1990. 2 v. 
MONTAIGNE, M. de. Os Ensaios. Ed. Pierre Villey, trad. Rosemary C. Abílio São Paulo: Martins Fontes, 2000.

PASCAL, B. Pensamentos. Ed. Louis Lafuma, trad. Mário Laranjeira São Paulo: Martins Fontes, 2001.

.Pensées de M. Pascal sur la religion et quelques autres sujets. Paris: Guillaume Desprez, 1670.

POPKIN, R. H. História do Ceticismo de Erasmo a Spinoza. Trad. Danilo Marcondes de Souza Filho. Rio de Janeiro: Francisco Alves, 2000.

QUANTIN, J-L. La Raison, la Certitude, la Foi: quelques remarques sur les préliminaires de l'acte de foi selon Huet. In: GUELLOUZ, S. (Ed.). Pierre-Danil Huet (1630-1721). Actes du Colloque de Caen (12-13 Novembre 1993), Papers on French Seventeenth Centuruy Litterature. Biblio, Paris/Seattle/Tübingen, v. 17, p. 83-97, 1994. RAPETTI, E. Percorsi Anticartesiani nella Lettere a Pierre-Daniel Huet. Firenze: Olschki, 2003.

SEXTO EMPÍRICO. Outlines of Pyrrhonism. Trad. R. G. Bury. Cambridge, MS: Harvard University Press, 1933. (Loeb Classical Library) 